
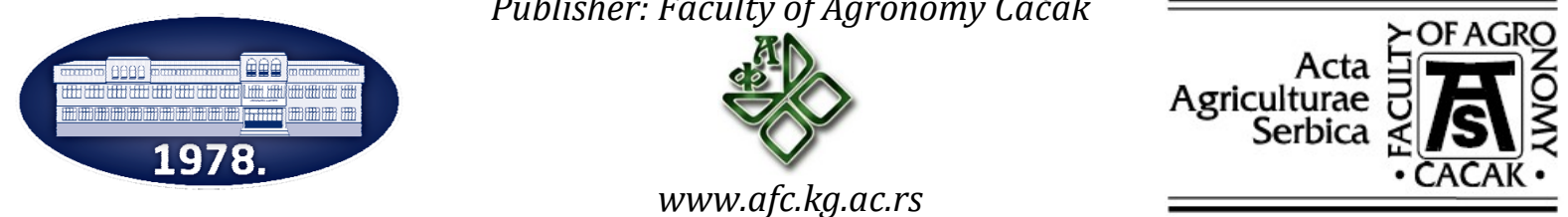

\title{
The effect of a plant mixture (garlic, mint and rosemary) on production and slaughter indicators in broiler chickens
}

\author{
Veselin Petričević ${ }^{*}$, Miloš Lukić1 ${ }^{1}$ Zdenka Škrbić ${ }^{1}$, Maja Petričević1,

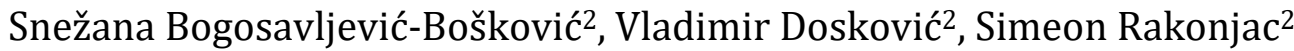 \\ ${ }^{1}$ Institute for Animal Husbandry, Autoput 16, 11080, Belgrade-Zemun, Republic of Serbia \\ ${ }^{2}$ Faculty of Agronomy in Čačak, University of Kragujevac, Čacak, Republic of Serbia \\ *Corresponding author: veselin5@live.com
}

Received 10 October 2020; Accepted 19 November 2020

\begin{abstract}
A B S T R A C T
The study objective was to examine the effect of the addition of different concentrations of a mixture of three plants (garlic, mint and rosemary) in the diet of broiler chickens on production and slaughter results. The mixture was formed by grinding plants after drying and mixing them in a ratio of 1: 1: 1 . The experiment was performed on 600 chickens divided into 4 groups with 3 replicates per group. The chickens were fed at will and the composition of the diet differed only in the amount of added mixture. No mixture was added in control group (C). Group MIX-I chickens consumed a diet supplemented with $0.25 \%$ of the mixture, group MIX-II diet contained $0.5 \%$ of the mixture supplement, while group MIX-III broilers received $0.75 \%$ of the mixture in their diet. At the end of the experimental period, at the age of 42 days, the body weight of the chickens was measured. Mortality, feed conversion and EPEF were determined. At the end of the experiment, 12 chickens ( 6 males and 6 females) were sacrificed by random sampling from each group in order to determine slaughter results. The obtained results showed that the use of the mixture of three plants had a positive effect on the production parameters. MIX-II group chickens had significantly higher $(p<0.01)$ body weights, better feed conversion and significantly higher $(p<0.01)$ EPEF values compared with $C$ group. No significant differences in slaughter performances were found.
\end{abstract}

Keywords: nutrition, chickens, phytobiotics, production and slaughter performances.

\section{И 3 В О д}

Циљ ових истраживања био је да се испита утицај додавања различитих концентрација мешавине три биљке (белог лука, нане и рузмарина) у исхрани бројлерских пилића на производне и кланичне резултате. Наведена мешавина је формирана тако што су биљке након сушења самлевене и помешане у односу 1:1:1. Оглед је изведен на 600 пилића, који су подељени у 4 групе са 3 понављања по групи. Пилићи су храњени по вољи, а састав смеша се једино разликовао у количини додате мешавине. У контролној групи (C) није додавана мешавина. Пилићи MIX-I групе су конзумирали смеше са додатком 0,25\% мешавине, у групи MIX-II додато је 0,5\%, док је у групи MIX-III додато 0,75\% мешавине. На крају огледног периода, у узрасту пилића од 42 дана, извршено је мерење телесне масе пилића. Утврђен је морталитет, конверзија хране и EPEF. На крају огледа методом случајног узорка из сваке групе жртвовано је по 12 пилића (6 мушких и 6 женских) у циљу утврђивања кланичних резултата. Добијени резултати су показали да коришћење мешавине три биљке има позитиван утицај на производне параметре. Пилићи MIX-II групе су имали значајно веће (р<0.01) телесне масе, бољу конверзију хране и значајно већу (p<0.01) вредност EPEF у односу на С групу. Нису утврђене значајне разлике у кланичним резултатима.

Кључне речи: исхрана, пилићи, фитобиотици, производни и кланични резултати.

\section{Introduction}

The need to use phytobiotics in poultry nutrition has become increasingly important following the ban on the use of antibiotics, which is in effect in many countries in Europe and the world. Consumers demand a healthy-safe product. The advantage of using phytobiotics over antibiotics is the fact that there is no possibility of bacterial resistance. Windisch et al. (2008) have found that phytogenic additives lead to a more favorable ratio of bacteria in the digestive tract, thus improving production results. The group of phytogenic additives is comprised of substances that come from medicinal plants and herbs and spice plants. Whether used as whole parts of plants or in the form of essential oils, phytogenic additives can have a positive effect on animal health. Lee et al. (2003) have reported that the use of phytobiotics improves production results. To determine the effects of the addition of phytobiotics to chicken feed on production and slaughter results, Al-Kassie and Witwit (2010) used a mixture of several medicinal plants.

Konjufka et al. (1997) have determined the antimicrobial and antioxidant properties of garlic. The characteristic smell and aroma of garlic comes from allicin (Rahmatnejad and Roshanfekr, 2009). Mint (Mentha piperita L.) and rosemary (Rosmarinus officinalis) are plants of the Lamiaceae family. These plants are characterized by a pronounced odor that originates from the leaves and they can be used as an 
herbal remedy. Moreno et al. (2006) have reported the antimicrobial and antioxidant activity of rosemary in their study. In contrast, Issa and Omar (2012) have found no significant impact of supplemental phytobiotics on the production results of chickens. Given the results so far, the use of phytobiotics in the diet can have a significant impact, but it is important to determine the optimal combination and dose of phytobiotics.

The aim of this study was to examine the effect of dietary supplementation of different concentrations of a mixture of three plants (garlic, mint and rosemary) on the production and slaughter performance of broiler chickens.

\section{Materials and methods}

The experimental material consisted of 600 oneday-old broiler chickens of the Ross 308 hybrid. The chickens were divided into 4 groups and placed in 12 boxes ( 50 chickens per box). During the study, broilers were fed 3 diets, the composition of which is given in Table 1. Feeding was at will, and the composition of the diets differed only in the amount of added plant mixture. The mixture was formed by grinding plants after drying and mixing them in a ratio of $1: 1: 1$. No mixture was added in control group (C). Chickens of group MIX-I consumed a diet supplemented with $0.25 \%$ of the mixture, group MIX-II diet contained $0.5 \%$ of the mixture supplement, and group MIX-III broilers received $0.75 \%$ of the mixture in their diet.

Table 1.

The composition of diets used in the experiment

\begin{tabular}{llll}
\hline Ingredient, \% & Starter & Grower & Finisher \\
& $0-14 \mathrm{~d}$ & $15-35 \mathrm{~d}$ & $26-42 \mathrm{~d}$ \\
\hline Corn & 53.2 & 58.2 & 63.2 \\
Soybean meal & 34 & 28 & 23 \\
Full fat soybeans (extruded) & 7 & 7 & 7 \\
Vegetable oil & 2 & 3 & 3 \\
Limestone & 1.4 & 1.4 & 1.4 \\
Monocalcium phosphate & 1.2 & 1.2 & 1.2 \\
Salt & 0.2 & 0.2 & 0.2 \\
Premix & 1 & 1 & 1 \\
Total & 100 & 100 & 100 \\
Nutrients and energy level (calculated) & & & 13.3 \\
ME, MJ/kg & 12.6 & 13.1 & 18.0 \\
Crude protein, \% & 22.0 & 19.8 & 7.03 \\
Crude fat, \% & 5.77 & 6.88 & 2.97 \\
Crude fiber, \% & 3.40 & 3.16 & 0.96 \\
Lysine, \% & 1.26 & 1.09 & 0.52 \\
Methionine + Cystine, \% & 0.63 & 0.57 & 0.96 \\
Ca, \% & 1.01 & 0.98 & 0.58 \\
P, \% & 0.62 & 0.59 & \\
\hline
\end{tabular}

Mortality and feed consumption were monitored at the box level; therefore, in statistical data processing, box was the unit of observation. At the end of the study, at the age of 42 days, the body weight of all chickens was measured and the conversion of feed was calculated. Based on the data on body weight, feed conversion and mortality, the value of the European Production Efficiency Factor (EPEF) was calculated, according to the formula:

$$
\text { EPEF }=\frac{\text { Body weight }(\mathrm{kg}) \times \text { Vitality }(\%) \times 100}{\text { Duration of fattening (days) } \text { x Feed conversion }(\mathrm{kg} / \mathrm{kg})}
$$

After the fattening period, 6 male and 6 female chickens from each group were selected by the method of a completely random sample, measured and slaughtered after 12 hours of fasting. After slaughter and processing, cooled carcasses were measured in accordance with the Ordinance on the Quality of Poultry Meat (1981). Hence, "ready to grill" carcasses carcasses without edible internal organs, necks and legs - were obtained. During the processing of the carcass, abdominal fat i.e. adipose tissue unattached to the carcass was separated. After carcass dissection, basic carcass parts (breast, thighs, drumsticks, wings) and the liver, heart and stomach were weighed. The obtained carcass weights, abdominal fat, basic carcass parts and internal organs were compared with the preslaughter body weight of the chickens. In that way, "ready to grill" yields, as well as the shares of abdominal fat in the carcass basic carcass parts, the liver, the heart and the stomach, were obtained.

The obtained data were statistically processed using the software package STATISTICA. The Tukey test was used to determine the statistical significance of differences between individual mean values.

\section{Results and discussion}

The effects of the addition of a phytobiotic mixture in the diet of broiler chickens on production performance are shown in Table 2. 
Table 2.

Production performance

\begin{tabular}{llllll}
\hline \multirow{2}{*}{ Production parameters } & \multicolumn{2}{l}{ Treatments } & & & \\
\cline { 2 - 5 } & $\mathrm{C}$ & MIX-I & MIX-II & MIX-III & p-value \\
& $(0 \%)$ & $(0.25 \%)$ & $(0.5 \%)$ & $235 \%)$ & \\
\hline Body weight, g & $2186.2^{\mathrm{c} \pm 381.4}$ & $2360.0^{\mathrm{ab}} \pm 374.4$ & $2445.2^{\mathrm{a} \pm 351.3}$ & $2325.6^{\mathrm{abc} \pm 332.1}$ & $\mathrm{p}<0.01$ \\
Mortality, \% & 3.33 & 3.33 & 0.00 & 0.00 & \\
Feed conversion, kg/kg & $1.95 \pm 0.10$ & $1.82 \pm 0.12$ & $1.76 \pm 0.03$ & $1.82 \pm 0.05$ & 0.126 \\
EPEF & $259.08^{\mathrm{b}} \pm 27.43$ & $294.44^{\mathrm{ab} \pm 35.55}$ & $330.17 \mathrm{a} \pm 12.21$ & $303.81^{\mathrm{ab} \pm 13.28}$ & $\mathrm{p}<0.01$ \\
\hline
\end{tabular}

Values are presented as $\bar{x} \pm \mathrm{Sd}$

a-c: Values within rows with different superscripts are significantly different $(p<0.01)$

Chickens fed diets supplemented with medicinal plants had higher final body weights compared with chickens of the control group. Chickens of the MIX-II group had significantly higher $(\mathrm{p}<0.01)$ body weights compared with the $C$ group. Mortality was higher in control and MIX-I broilers than in those receiving a higher proportion of the mixture. The conversion of chicken feed did not differ significantly under the influence of the phytobiotic supplementation. Feed conversion improved with the increase in the proportion of the plant mixture to a concentration of $0.5 \%$. The EPEF as the most comprehensive production indicator was statistically significantly affected $(\mathrm{p}<0.01)$ by the examined factor. As the mixture content in the diet increased, the EPEF gradually increased to the mixture concentration of $0.5 \%$. A significantly lower $(\mathrm{p}<0.01)$ value of the EPEF was found in the control group (259.08) compared with the MIX-II group (330.17). As the concentration of the mixture in the diet increased to over $0.5 \%$, body weight decreased, feed conversion worsened and the EPEF value decreased.

The obtained results indicate the importance of using these plants, which is reflected in higher body weight, better feed conversion, more favorable mortality and higher EPEF values. Our research findings are consistent with the results of NarimaniRad et al. (2011), who reported an improvement in production performance as a result of using a mixture of phytobiotics. The increase in the concentration of active ingredients of the phytobiotics used in the mixture (up to a concentration of $0.5 \%$, group MIX-II), led to higher body weights and better feed conversion. A further increase in the concentration of the plant mixture caused decreases in body weights, feed conversion and EPEF values. Better feed conversion in chickens fed diets supplemented with plants can be attributed to the antimicrobial activities of phytogenic additives that improve the utilization of nutrients in the digestive tract of chickens. In a study by Ghazalah and Ali (2008), the use of rosemary at a concentration of $0.5 \%$ in chicken diet resulted in significantly better production results compared with broilers receiving diets supplemented with a higher concentration of this nutrient and those fed diets without this nutrient. As explained by the authors, with increasing concentration of rosemary, the level of crude fiber in mixtures increased, which interfered with the utilization of nutrients. In our study, higher mortality was recorded in $\mathrm{C}$ and MIX-I groups than in the other groups. AlKassie (2010) reported lower mortality in chickens fed mixtures with $0.5 \%$ mint compared with the control, which can be explained by the presence of active ingredients of mint essential oils that favor the microbiological composition of the intestines and improve chicken vitality.

The results on the ready-to-grill slaughter yield, shares of abdominal fat in the carcass, basic carcass parts, and the liver, heart and stomach in the examined broiler chickens are shown in Table 3.

Table 3.

Slaughter performance

\begin{tabular}{llllll}
\hline \multirow{2}{*}{ Shares, \% } & \multicolumn{2}{l}{ Treatments } & & & p-value \\
\cline { 2 - 5 } & $\mathrm{C}$ & MIX-I & MIX-II & MIX-III & \\
$(0.25 \%)$ & $0.75 \%)$ & 0.718 \\
\hline Carcass weight & $69.96 \pm 1.64$ & $69.88 \pm 1.33$ & $69.35 \pm 1.31$ & $69.80 \pm 1.30$ & 0.249 \\
Abdominal fat & $1.64 \pm 0.44$ & $1.33 \pm 0.45$ & $1.31 \pm 0.48$ & $1.30 \pm 0.28$ & 0.399 \\
Breast & $26.81 \pm 1.46$ & $27.92 \pm 1.98$ & $27.04 \pm 1.86$ & $27.21 \pm 1.27$ & 0.756 \\
Thighs & $9.70 \pm 0.40$ & $9.51 \pm 0.66$ & $9.53 \pm 0.68$ & $9.68 \pm 0.38$ & 0.150 \\
Drumsticks & $11.04 \pm 0.45$ & $10.48 \pm 0.58$ & $10.53 \pm 0.50$ & $11.00 \pm 0.55$ & 0.116 \\
Wings & $7.78 \pm 0.45$ & $7.43 \pm 0.30$ & $7.54 \pm 0.46$ & $7.70 \pm 0.29$ & 0.381 \\
Liver & $1.62 \pm 0.20$ & $1.74 \pm 0.20$ & $1.69 \pm 0.16$ & $1.74 \pm 0.18$ & 0.999 \\
Stomach & $1.47 \pm 0.17$ & $1.46 \pm 0.17$ & $1.47 \pm 0.22$ & $1.46 \pm 0.24$ & 0.370 \\
Heart & $0.45 \pm 0.07$ & $0.43 \pm 0.04$ & $0.39 \pm 0.04$ & $0.43 \pm 0.05$ & \\
\hline
\end{tabular}

Values are presented as $\bar{x} \pm \mathrm{Sd}$

The "ready to grill" slaughter yield, as well as the shares of abdominal fat, basic carcass parts, liver, heart and stomach, were not statistically significantly affected by the examined factor. The increase in the concentration of the phytobiotic mixture in the feed rations of the chickens did not result in significant 
differences in any of the examined carcass quality parameters. Our results are in agreement with the study of Ocak et al. (2008), who examined the effects of $0.2 \%$ mint supplementation on the production and slaughter performance of chickens and found no significant differences in the share of yield and edible internal organs. Zhang et al. (2005) found no significant differences in carcass shares in broilers fed diets supplemented with a mixture of different essential oils, compared with the control group. Hernández et al. (2004) reported no effect of using different plant extracts in the diet of broiler chickens on the weight of internal organs.

\section{Conclusions}

The results of the examination of the effect of plant mixture supplementation on the production performance and carcass quality of broiler chickens indicate that chickens fed diets supplemented with $0.5 \%$ mixture (group MIX-II) had significantly higher $(p<0.01)$ body weights and significantly higher $(\mathrm{p}<0.01)$ EPEF values compared with the control group. A further increase in the concentration of the mixture in the diet (group MIX-III) caused a deterioration of the production properties. Carcass quality parameters did not differ significantly under the influence of the examined factor.

\section{Acknowledgments}

This work was supported by the Ministry of Education, Science and Technological Development of the Republic of Serbia, Contracts Nos. 451-03-68/2020$14 / 200022$ and 451-03-68/2020-14/200088.

\section{References}

Al-Kassie, G.A.M. (2010). The role of peppermint (Mentha piperita) on performance in broiler diets. Agriculture and Biology Journal of North America, 1(5), 1009-1013.

Al-Kassie, G.A.M., Witwit, N.M. (2010). A comparative study on diet supplementation with a mixture of herbal plants and dandelion as a source of probiotics on the performance of broilers. Pakistan Journal of Nutrition, 9(1), 67-71.

Ghazalah, A.A., Ali, A..M. (2008). Rosemary leaves as a dietary supplement for growth in broiler chickens. International Journal of Poultry Science, 7(3), 234-239.

Hernandez, F., Madrid, J., Garcia, V., Orengo, J., Megias, M.D. (2004). Influence of two plant extracts on broilers performance, digestibility and digestive organ size. Poultry Science, 83, 169-174.

Issa, K. J., Omar, J. M. A. (2012). Effect of garlic powder on performance and lipid profile of broilers. Open Journal of Animal Sciences, 2, 62-68.

Konjufka, V., Pesti, G., Bakalli, R. (1997). Modulation of cholesterol levels in broiler meat by dietary garlic and copper. Poultry Science, 76, 1264-1271.

Lee, K.W., Everts, H., Kappert, H.J., Frehner, M., Losa, R., Beynen, A.C. (2003). Effects of dietary essential oil components on growth performance, digestive enzymes and lipid metabolism in female broiler chickens. British Poultry Science, 44(3), 450-457.

Moreno, S., Scheyer, T., Romano, C.S., Vojnov, A.A. (2006). Antioxidant and antimicrobial activities of rosemary extracts linked to their polyphenol composition. Free Radical Research, 40(2), 223-231.

Narimani-Rad, M., Nobakht, A., Aghdam Shahryar, H., Kamani, J., Lotfi, A. (2011). Influence of dietary supplemented medicinal plants mixture (Ziziphora, Oregano and Peppermint) on performance and carcass characterization of broiler chickens. Journal of Medicinal Plants Research, 5(23), 5626-5629.

Ocak, N., Erener, G., Burak, F., Sungu, M., Altop, A., Ozmen, A. (2008). Performance of broilers fed diets supplemented with dry peppermint (Mentha piperita) or thyme (Thymus vulgaris) leaves as growth promoter source. Czech Journal Animal Science, 53, 169-175.

Ordinance on the quality of poultry meat (1981). Gazette SFRJ No. 1, 13-14.

Rahmatnejad, E., Roshanfekr, H. (2009). Evaluation the effect of several non-antibiotic additives on growth performance of broiler chickens. Journal of Animal and Veterinary Advances, 8, 1757-1760.

Windisch, W., Schedle, K., Plitzner, C., Kroismayr, A. (2008). Use of phytogenic products as feed additives for swine and poultry. Journal of Animal science, 86(14), 140-148.

Zhang, K.Y., Yan, F., Keen, C.A., Waldroup, P.W. (2005). Evaluation of microencapsulated essential oils and organic acids in diets for broiler chickens. International Journal of Poultry Science, 4(9), 612-619. 